\title{
Elements of Biology in Aristotle's Political Science
}

\author{
Elena Cagnoli Fiecconi
}

Draft please cite published version (forthcoming 2019)

Aristotle's political science studies the human good. This includes the good for individuals and the good for the community, which is greater, more complete and more divine (EN 1.2, 1094a27-1094b11). Thus, while we tend to treat ethics and politics as separate disciplines with some points of common interest, Aristotle treats them as the same discipline (Schofield 2006). A paradigmatic example of this aspect of Aristotle's thought is his study of virtues of character like generosity or temperance. Studying the virtues is obviously important to understand individual moral excellence and happiness. However, the virtues are also interesting for political scientists who focus on the good for the community, because their main aim is to make the citizens virtuous (EN 1.13, 1102a5-10).

Political science (episteme) is not the only discipline that concerns itself with the virtues. From the perspective of a contemporary reader, Aristotle is peculiar because he studies ethically relevant phenomena like the virtues in his biological treatises. The History of Animals 8-9 (esp. 9) catalogues character traits like mildness and courage in different non-human animal species. At EN 6.13, 1144b1-16, these are "natural virtues", they are shared between non-human animals and human children and they are the source of fully blown virtues in human adults. ${ }^{1}$ Related passages of the Parts of Animals discuss the physiological basis of these virtues and connect it to the constitution of the animal's blood (PA 2.2, 648a9-11; PA 2.4, 650b20-651a2; PA 2.4, 651a12-14; PA 4.10, 686b25-27).

The case of the virtues is not isolated: there are many instances of overlap between topics in Aristotle's biology and political science. These include the natural sociability of human beings (Pol. 1.2, 1252b28-33) and the controversial idea that humans have a function or characteristic activity (ergon, EN 1.7).

Political science and biology clearly are not the same discipline. Political science is practical and aims at guiding action, biology and natural science in general aim at discovering the truth. ${ }^{2}$ However, in light of the overlaps between the two disciplines, it is fruitful to ask whether Aristotle's views in biology influence or explain some of his theses in political science. ${ }^{3}$ In the first section of this chapter, I argue that there are some cases in which Aristotle endorses biological theses as the background of his ethical enquiry and cases in which biological arguments independently explain his ethico-political theses. An example of the first case is the study of the characteristic

\footnotetext{
${ }^{1}$ EN 6.13, 1144b1-16; HA 8.1, 588a25. The fact that our natural virtues are embedded in a context of habituation and teaching does not make them different from non-human natural virtues. At least some non-human animals can be habituated and taught too (HA 9.1, 608a16-20). See further (Lennox 1999, reprinted in Henry and Nielsen 2015).

${ }^{2}$ EN 1.2, 1095a5-6; EN 2.1, 1103b25-28; EN 6.2, 1139a25-30; EN 6.7, on the view that Aristotle's ethics and natural science are linked see inter alia (Henry and Nielsen 2015, Introduction; Leunissen 2015a; Leunissen 2017, xxiii). Against this view see inter alia (Barney 2008; Kraut 2018, 3.2).

${ }^{3}$ Another good question, which I will not be able to tackle here, concerns the way in which Aristotle's political science influences his biology. See further (Merleau 2003; Spelman 2003).
} 
activity of different kinds of living beings, an example of the second is the view that the formation of city-states is natural. In other contexts, though there is an overlap between his biology and his political science, it is harder to establish if there is an explanatory relationship between the two. This is the case for Aristotle's political and biological elitism and sexism.

In the second section, I suggest that, despite the agreement and reciprocal support between the two disciplines, sometimes Aristotle's biology gives us reason to question his ethico-political views: this happens in his discussion of the possibility of justice between human and non-human animals and in his exhortation toward theoretical contemplation.

If this is right, a study of Aristotle's biology can guide both a clarification and an internal critique of his political science and his ethics. In addition, since Aristotle's biology is outdated, examining its link with his ethics enables us to assess more accurately the extent to which an Aristotelian ethics is still viable today.

\section{Political Nature, Human Function and the Virtues}

In the Politics, Aristotle argues that the city-states (poleis) are the natural form of association for humans:

Hence every city-state exists by nature, just as the first communities; for the city-state is the end of these communities, and nature is an end, since that which each thing is when its growth is completed we call its nature, no matter if we are speaking of a human being, a horse, a household. ... From these things therefore it is clear that the city-state is natural, and that a human is by nature a political animal. ${ }^{4}$

In this passage, the generation of the city-state is a natural end for humans, who are by nature political animals. In order to explain what "nature" and "natural" mean in this context, it is helpful to look beyond the Politics and into the History of Animals. At HA 1.1, 488a7-8, Aristotle explains that being political animals means having one common function (koinon ergon) with members of the same species. This political nature belongs to humans, but also to bees, cranes and wasps. Only humans, however, perfect their political nature and their common function by living and exercising reason together in city-states. This explains why humans are political to a higher degree (mallon) than the other political animals (Pol. 1.2, 1253a7-8). ${ }^{5}$

Another obvious case of overlap between Aristotle's biology and his political science is his thesis that humans have a function. This thesis plays an important role in the "function argument" at the very beginning of the Nicomachean Ethics. According to the function argument, if something has function, its good depends on its function, i.e. its characteristic or proper activity. The function of humans is rational activity and virtue

\footnotetext{
${ }^{4}$ Pol. 1.2, 1252b30-1253a3. Trans. loosely based on (Rackham 1932).

${ }^{5}$ The relationship between human and non-human political animals in the Politics and in the History of Animals is investigated in detail by (Cooper 1988; Depew 1995; Karbowski forthcoming).
} 
enables humans to perform this activity well. ${ }^{6}$ From this Aristotle concludes that the human good is a reason-involving activity in accordance with virtue (EN 1.7, 1097b221098a18).

For the purposes of this chapter, let us leave aside the much discussed and controversial validity of the function argument as a whole. ${ }^{7}$ Instead, let us focus more specifically on one of the assumptions it relies upon, i.e. the thesis that humans have a function: ${ }^{8}$

For just as the good, i.e., [doing] well, for a flautist, a sculptor, and every craftsman, and, in general, for whatever has a function and [characteristic] action, seems to depend on its function, the same seems to be true for a human being, if a human being has some function. Then do the carpenter and the leather worker have their functions and actions, but has a human being no function? Is he by nature idle, without any function (argon)? Or, just as eye, hand, foot, and, in general, every [bodily] part apparently has its function, may we likewise ascribe to a human being some function apart from all of these? ${ }^{9}$

Aristotle uses a series of rhetorical questions to introduce the thesis that humans have a function. The first rhetorical question suggests that it would be odd if humans in general did not have a function, since craftsmen in particular do. The second question indicates an analogy between biological organisms and their parts: a whole organism has its own separate function just as its constituent parts have a function. This analogy just points out a similarity between the whole and its parts, it does not imply that we can infer that the whole organism has a function from the fact that its parts do. However, we do find exactly this inference in the biological works. At PA 1.5, 645b1420 , Aristotle argues that since its parts have a function, the whole organism has a function, which he calls a multiform (polymerous) activity. ${ }^{10}$ Hence, since our eyes and ears have a function (seeing and hearing), we as unified organisms have a function.

Stated in this simple form, this argument is threatened by the fallacy of composition, i.e. it relies on the mistaken assumption that what is true of its parts is always true of the whole. It is easy to find counterexamples to this assumption: the roof of my house is made of wood, but the whole house is not. However, Aristotle here is on stronger grounds than he seems to be. In the case of a living organism, we can move from the function of the parts to the function of the whole, because the specific functions of the parts can be understood only in light of the function of the whole. ${ }^{11}$

${ }^{6}$ The good and happy life for humans is a life of virtuous activity. In order to live this kind of life, humans need virtue and other goods including, for example, friendship (EN 1.8, 1099a31b6).

${ }^{7}$ See further (Whiting 1988) for a helpful summary of the controversies the function argument raises and a proposed solution.

${ }^{8}$ I follow (Shields 2015; Leunissen 2015a) contra (Barney 2008) in assuming that Aristotle, in the Nicomachean Ethics, does not argue for the conclusion that humans have a function. Rather, he expects his readers to accept that humans have a function and he investigates the nature of this function.

${ }^{9}$ EN 1.7, 1097b25-33. Translations of the EN are based, sometimes loosely, on (Irwin 1999).

${ }^{10}$ A textual variant at PA 1.5, 645b17 has plerous (full or complete) instead of polymerous (multiform). The variants do not make much difference for my purposes here because it is clear that Aristotle has in mind a single unified activity of the living organism, and not just the collection of the activities characteristic of its parts.

${ }^{11}$ A version of this argument is proposed by (Tuozzo 1996, 149-51, see also Leunissen 2015a, 229). 
It is helpful to keep in mind, in this context, that Aristotle takes an organism's function to be its characteristic activity. In turn, characteristic activities are often hierarchically organized (PA 1.5, 645b28-30; Pol.1.2, 1253a20-25). The activity of a bodily part, for example the seeing of the eye, is not self-standing, but it is subordinate to other activities like reproduction and feeding. This suggests that we can only understand the seeing of the eye if we understand that it is for the sake of the whole animal's characteristic life. Seeing is not for the sake of picking up a color-datum, but it is for the sake of recognizing food or a potential mate. Hence, it makes sense to suppose that a living organism has its own separate function or functions that explain the subordinate functions of its parts.

The biological teleology of the Parts of Animals backs up the thesis that humans have a function, which is one of the cornerstones of Aristotle's ethico-political theory. Nonetheless, it is difficult to prove that Aristotle intended the readers of the Nicomachean Ethics to accept the function thesis on the basis of their background knowledge of the relationship between parts and wholes of biological organisms. At EN 1.13, political scientists need to study some psychology, but they are not required to achieve the high degree of exactness characteristic of natural scientists. Similarly, political scientists may be expected to have some knowledge of natural teleology. However, it is less plausible to expect them to move from an analogy between parts and wholes to an argument that infers the function of the whole from the function of its parts. ${ }^{12}$

In contrast, some knowledge of biology is presupposed in the discussion of the nature of the human function at EN 1.7, 1097b33-1098a9:

What, then, could this [function] be? For living is apparently shared with plants, but what we are looking for is the characteristic (idion) function of a human being; hence we should set aside the life of nutrition and growth. The life next in order is some sort of life of sense perception; but this too is apparently shared with horse, ox, and every animal. The remaining possibility, then, is some sort of life of action of the [part of the soul] that has reason $(\log o n)$.... We have found, then, that the human function is activity of the soul in accord with reason or requiring reason. ${ }^{13}$

Here, Aristotle considers only three hierarchically ordered activities as candidates for the human function: the life of nutrition and growth, the life of perception and the life of action involving reason. He excludes the life of nutrition and the life of perception because they are shared between humans and other living beings, including plants and non-human animals. ${ }^{14}$ Since the human function is characteristic of humans, it cannot be characteristic of other living beings. ${ }^{15}$ On the basis of this criterion, he concludes that the function of humans is an activity of the soul in accordance with reason.

The candidates for the human function and the criterion for their exclusion seem arbitrary unless we read this passage having in mind the taxonomy of living beings in De Anima, Aristotle's treatise on psychology: nutritive and generative activities characterize the specific form of life of plants (de An. 2.3, 414a30-414b20); the life of

\footnotetext{
${ }^{12}$ The degree of scientific knowledge presupposed by the Nicomachean Ethics is debated. See inter alia (Irwin 1980; Barney 2008, 303; Leunissen 2015a; Shields 2015).

${ }^{13}$ EN 1.7, 1097b33-1098a9.

${ }^{14}$ For Aristotle, all living beings, including plants, have a soul (de An. 2.4, 415a24-25).

${ }^{15}$ Characteristic here translates idion. The meaning of idion in the function argument is debated, see further (Whiting 1988).
} 
understanding characterizes humans; the life of perception characterizes non-human animals (de An. 3.12, 434a22-32). These soul functions define three kinds of living beings and order them hierarchically according to their sophistication. When he presents only three possible candidates for the human function in the Nicomachean Ethics, Aristotle expects his readers to have this classification in mind. He is not interested in examining all the possible human activities or even all the vital human activities. He focuses only on the activities that differentiate and define the most basic kinds of living thing. ${ }^{16}$

If the discussion so far is right, Aristotle presupposes some knowledge of his biological taxonomy in the EN. In addition, his teleological biology gives some reasons for thinking that humans have a function. However, it is hard to assess whether these reasons were presupposed in the $E N$.

A further case of overlap between political science and biology is, as I noted in the introduction, the case of the virtues. In the Nicomachean Ethics, the virtues are character states that enable us to perform our function well and to live a morally good and happy life (EN 1.6, 1096a25; EN 2.6, 1106b36-1107a1). We acquire these virtues through habituation and teaching, but habituation and teaching do not start from scratch. Humans have in them the germs of virtue from birth:

For each of us seems to possess his type of character to some extent by nature; for in fact we are just, brave, prone to temperance, or have another feature, immediately from birth. But still we look for some further condition to be full goodness, and we expect to possess these features in another way. For these natural states belong to children and to beasts as well [as to adults], but without understanding they are evidently harmful. ${ }^{17}$

Humans are by nature prone to acquire full-blown character virtues because they possess "natural virtues". These natural virtues are shared between human children and non-human animals, but they can develop into fully blown character virtues only in human adults. This restriction applies because only human adults have reason (logos) and full-blown virtue requires excellent rational and deliberative capacities (EN 6.13, 1144b16-17).

Aristotle's view that the natural virtues are shared between human children and non-human animals leads us to his investigations on virtues and character traits in the Parts of Animals and in the History of Animals. ${ }^{18}$ By turning to these treatises, we learn that natural virtues have material preconditions and that they are correlated with different blood constitutions. PA 2.4 suggests that thick and fibrous blood is a precondition of bravery, while thin and watery blood is a precondition of cowardice. Differences in the constitution of one's blood are correlated with differences in courage and intelligence (PA 2.2, 648a9-11; PA 4.10, 686b25-27). These differences can be inter-specific, like the difference between timid ants and choleric bulls (PA 2.4, 650b20-651a2), or intraspecific, like the difference between brave people who live in cold regions and cowardly people who live in hot regions (Pol. 7.7, 1327b18-38).

It is striking to note, in addition, that fully blown character virtues also have material preconditions. Character virtues arise from psychic changes brought about by teaching and habituation, but these psychic changes have a physiological counterpart (see

\footnotetext{
${ }^{16}$ See (Irwin 1980; Leunissen 2015a; Shields 2015).

${ }^{17}$ EN 6.13, 1144b4-9

18 (Lennox 1999).
} 
especially Physics vii 3). At Ph. 7.3, 247a5-9 and at MA 1.8, 701b33-38, the bodily pleasures that guide moral habituation are accompanied by heathings and chillings. These heathings and chillings can presumably alter the constitution of one's blood, thus generating a state more or less suitable for certain virtues. For example, cold blood is less prone to boil in anger and thus it is less suitable for courage than hot blood (PA 2.2, 648a1-4). ${ }^{19}$ Elsewhere in the corpus, Aristotle mentions diet, exercise and ageing among the causes of the transition from natural virtue to character virtues (Pol. 7.17, 1336a38; Pol. 8.2, 1337b22-28; Pol. 8.3, 1338a31-b8; Pol. 8.5, 1338b39-1339a10; EN 4.1, 1121a20-21).

These correlations raise a difficult question about the link between the constitution of one's blood and one's character state: does Aristotle think that one's bravery or generosity can be caused by one's blood constitution? Or does he think that one's character states and their correlative physiology are ultimately explained by facts about the human formal essence (the rational soul)?

Some interpreters give causal priority to formal essence over the material preconditions of the virtues. They appeal to the fact that, in Aristotle's biology, formal and final causes that relate to a being's essence have explanatory priority over material causes. For example, the body develops in a certain way for the sake of the functions of the soul (PA 1.1, 642a9-13; PA 1.5, 645b14-20). We have perceptual organs of a certain kind because we are perceptive living things, birds have wings because they are fliers. Similarly, the material correlates of our character states should be explained by our soul or our form, because our soul requires them for its characteristic functions. ${ }^{20}$

Other interpreters resist the causal priority of form in the case of character virtues. ${ }^{21}$ They argue that a virtue is not necessarily an essential characteristic of an animal kind. Hence, it may not be due to the form of the animal kind..$^{22}$ Thus, the virtues may be similar to the emotions, whose cause can be a bodily process, a psychic process, or a process with both psychic and bodily aspects. ${ }^{23}$ If this is right, the material cause of a character state (the constitution of the blood, PA 2.4, 651a12-14) can be its primitive cause.

Looking at the status of the material causes of the virtues is a good way to shed light on Aristotle's views on the genesis of a virtuous character and on its preconditions. In addition, the debate on the status of these causes weighs on one's assessment of the plausibility of Aristotle's ethics and political science. If material causes are primitive and explain the insurgence of the virtues, it is hard to see how Aristotle's views on the genesis of a virtuous character can survive his outdated science. If, instead, material causes are necessitated by a study of our rational formal nature, it may be easier to claim that Aristotle's view on the preconditions of the virtues can be updated and reconciled with modern science.

\footnotetext{
${ }^{19}$ See (Leunissen 2015b; Leunissen 2017, chap. 5) on the physiological counterpart of moral habituation in the Nicomachean Ethics provided by Physics vii 3. Unlike Leunissen, I think fully blown virtues (and not only natural virtues) can have material causes (Cagnoli Fiecconi 2018). ${ }^{20}$ See (Deslauriers 2009; Johansen 2012, 102-9; Gelber 2015a; Gelber 2015b; S. M. Connell 2016, chap. 4.5). This kind of material causation is debated, see further (Gill 1997; Lennox 1997; Leunissen 2010, 81-111), cf. inter alia PA 1.1, 639b29-640a9; PA 2.15, 658b23-26; PA 3.2, 663b2536; GA 5.1, 778a29-b1.

${ }^{21}$ (Leunissen 2012, 514-20, 2017, chaps 2-3).

22 (Leunissen 2017, xxi-xxiii and chap. 2).

${ }^{23}$ (de An. 1.1, 403a19-25, Cagnoli Fiecconi 2018).
} 
Similar considerations arise in relation to a study of the potential link between Aristotle's natural science and some of his most objectionable ethico-political views. Aristotle does not explicitly attempt to offer scientific justifications for his sexism and racism in the ethico-political works. However, it is tempting to look for these justifications in his natural science, for his natural science is equally fraught with biases against women and specific ethnicities. ${ }^{24}$ If a justificatory link of this sort can be proven, in turn, it may threaten to make Aristotle's ethics not only obsolete but also repellent. ${ }^{25}$

A recent reconstruction of this link can be found in Mariska Leunissen's work. On the basis of a study of Pol. 7.6, 1327b18-38, she argues that, for Aristotle, climate affects some of the material causes and preconditions of the virtues, including the constitution and temperature of the blood. Depending on where one grows up, one's blood will be hotter or colder, which determines one's intelligence, one's bravery and one's suitability for ruling. ${ }^{26}$ Similarly, on her interpretation, it is possible to connect Aristotle's views on the constitution of women's blood (GA 2.4, 738a33-b5; GA 4.1, 765b817; HA 3.19, 521a21-27) to his views on their alleged lack of courage and their alleged propensity to be ruled (HA 9.1, 608a25-608b16). ${ }^{27}$

In the Politics, the social relationships between Athenian men of high birth, women and slaves are unequal. Men rule, women and slaves obey:

The male is by nature superior (kreitton) and the female inferior (cheiron), the male ruler and the female subject. And the same must also necessarily apply to all humankind; ... For he is by nature a slave who can belong and therefore does belong to another, and who participates in reason (logou) so far as to apprehend it but not to possess it. ${ }^{28}$

Aristotle thinks that slaves and women partake in reason differently from men. This is why he believes it is right for them to be ruled:

Hence there are by nature various kinds of rulers and ruled. For the freeman rules the slave, the male the female, and the man the child in a different way. And all possess the various parts of the soul, but possess them in different ways; for the slave has not got the deliberative part at all, and the female has it, but without full authority (akuron), while the child has it, but it is immature. ${ }^{29}$

The rational part of the soul lacks deliberative powers in slaves, authority in women and maturity in children. This implies, Aristotle thinks, that women, children and slaves should be subject to different kinds of rule by freemen. Aristotle's claims about the physiological constitution of women, children and slaves can be linked to his views on their participation in reason. However, assessing the explanatory relevance of this link is difficult. First, even if Aristotle's biological works are sexist and elitist, it is not clear that he based his ethico-political sexism on his biology. Unlike the function argument, the description of the social roles quoted above does not make direct

\footnotetext{
${ }^{24}$ See (S. M. Connell 2016, chap. 1) for a list and criticism of recent and less recent attempts to draw this connection.

${ }^{25}$ (S. M. Connell 2018).

${ }^{26}$ (Leunissen 2017, chap. 2)

${ }^{27}$ (Leunissen 2017, 139-77). See however (S. M. Connell 2018) for a critique.

${ }^{28}$ Pol. 1.6, 1254b14-25

${ }^{29}$ Pol. 1.13, 1260a8-15
} 
reference to biological considerations. Furthermore, the overlap between political science and biology is not always perfect. For example, it is hard to square the claim that women have a rational part without authority with the claim that they are intelligent and can achieve virtue and happiness (HA 9.1, 608a28; Rhet. 1.5, 1361a1-10). ${ }^{30}$ It is easier to find coherence in Aristotle's equally horrific views about natural slavery, but even there he does not argue that there is a necessary connection between certain ethnicities and slavery. ${ }^{31}$ Hence, while it seems clear that both Aristotle's biology and his political science contain unjustified and biased views on women and "natural slaves", it is less clear whether and to what extent these biased views are meant to support each other.

The political nature of humans, the function argument and the material causes of virtue offer an impressive series of examples of the overlap between Aristotle's political science and his biology. In some cases, his biological teleology is clearly presupposed in his ethico-political views. In other cases, a justificatory connection can be drawn, even if it is not clear that Aristotle himself intended to make the connection. In other cases still, there are some elements of overlap between the two disciplines, but if a justificatory connection between the two can be drawn, it is bound to be to some extent speculative. In light of this evidence, it is all the more interesting to note that there are cases in which Aristotle's biology is in tension with his political science. To these cases I turn in the next section.

\section{Inter-Species Justice and Self-Improvement}

In the Nicomachean Ethics, Aristotle argues that there can be neither friendship nor justice between beings who have "nothing in common":

For where ruler and ruled have nothing in common (meden koinon), they have neither friendship, since they have no justice (dikaion) either. This is true for a craftsman in relation to his tool and for the soul in relation to the body. For in all these cases the user benefits what he uses, but there is neither friendship nor justice toward inanimate things. Nor is there any toward a horse or cow, or toward a slave, insofar as he is a slave. For master and slave have nothing in common, since a slave is a tool with a soul, while a tool is a slave without a soul. Insofar as he is a slave, then, there is no friendship with him. But there is friendship with him insofar as he is a human being. For every human being seems to have some relation of justice with everyone who is capable of community in law (nomou) and agreement (sunthekes). ${ }^{32}$

Since a human, a horse, or a cow have nothing in common, there is neither justice nor friendship between them, in the same way in which there is no justice between an

\footnotetext{
${ }^{30}$ See (Nielsen 2015) for a defence of the thesis that Aristotle's gender bias is based on his biological psychology. Nielsen argues that the reciprocal grounding of sexism in the two disciplines is circular, for Aristotle's psychology is itself politicised and gendered.

${ }^{31}$ On slavery, see (Heath 2008); on the physical constitution of barbarians and slavery see Pol. 1.5, 1254b15-34, Pol. 1.6, 1255a28-b2 and (Leunissen 2017, 50-52). For a study of the relationship between Aristotle's sexism in his reproductive biology and his sexism in the Politics see (Henry 2007; S. M. Connell 2016, 17-52).

${ }^{32}$ EN 8.11, 1161a32-1161b8.
} 
artisan and an inanimate tool. The same applies, for Aristotle, to masters and slaves, for he thinks that slaves are like tools. The comparison with inanimate tools suggests that the common or shared features that matter for justice have to do with a thing's soul (or lack thereof) and with its way of life. The context of the passage is a discussion of friendship and justice in family relationships (EN 8.12). Hence, the kind of justice Aristotle has in mind here includes not only legal justice, but in general virtue in relation to other agents and avoidance of wrongdoing (EN 5.1).

Aristotle subsequently qualifies the thesis that there is nothing in common between masters and slaves: the extent of his prejudice does not go as far as denying that slaves are human and have the capacity to participate in a community ruled by law and agreement. However, he does not qualify the claim about non-human animals. ${ }^{33}$ This is surprising because, even if Aristotle is consistent throughout his work in denying reason (logos) to non-human animals, ${ }^{34}$ in his biological works human and non-human animals have quite a lot in common. As HA 8.1, 588a17-b3; HA 9.1, 608a12-17, b5-8; PA 1.5, 645a3 and PA 1.5, 645b27 make clear, human and non-human animals share a number of physical and psychic features, including character traits, perceptual capacities and desiderative capacities. Other characteristics are in common only by analogy, for some non-human animals have something similar to human foresight (phronesis), skill (techne) and wisdom (sophia) (HA 9.1, 608a 11-15; HA 8.1, 588a17-b3).

Even if they can be used by humans for goals that are not their own, non-human animals are quite unlike tools because they are living things with their own characteristic functions. Furthermore, even if they lack reason, their psychological make-up resembles the human psychological make-up in many ways. Hence, nonhuman animals have, by Aristotle's own standards, a claim to justice and friendship even if they cannot actively take part in a legal community. ${ }^{35}$ After all, at EN 8.11, 1161a15-23, there are justice and friendship between parents and children, even if children have not yet developed their reasoning capacities and they do not take part in political agreements.

The thesis that there is some degree of justice and friendship between humans and animals, in addition, resurfaces in passages of the Eudemian Ethics and of the Politics that are clearly influenced by Aristotle's ethology and biology. At EE 8.2, 1236b5-10, there is at least a small degree of friendship for utility between humans and tame (hemeros) animals. This friendship is similar to the friendship between crocodiles and Egyptian plovers: crocodiles let these little birds pick leeches out of their mouth because it benefits them. ${ }^{36}$

In addition, at Pol. 1.8, 1256b15-25, Aristotle acknowledges that there is a kind of justice between human and non-human animals. In particular, he argues that hunting wild beasts is a form of just war:

\footnotetext{
${ }^{33}$ See (Sorabji 1993) for a discussion of the denial of reason and the moral status of animals in the ancient world.

${ }^{34}$ Inter alia, de An. 1.2, 404b4-6; de An. 2.3, 414b18-19; de An. 3.3, 428a19-24; PA 1.1, 641b7; Pol. 7.13, 1332b5; EN 1.7, 1098a3-4; Metaph. 980b28; Mem. 450a16.

${ }^{35} \mathrm{He}$ mentions the capacity to share laws and agreement as sufficient for a relationship regulated by justice, but he gives no reason to think that this capacity is necessary. See (Henry 2018 contra Sorabji 1993, 177-78) on the thesis that Aristotle's student Theophrastus believed that non-human animals partake in justice because they share an analogue of human reason.

${ }^{36} \mathrm{HA} 8.6,612 \mathrm{a} 22-23$, see further HA 8.1, on non-human animal intra and interspecific friendship.
} 
Hence, in a way, the art of war is by nature an art of acquisition (for the art of hunting is a part of it) that is properly employed both against wild beasts (theria) and against those humans who, though they are disposed by nature to be governed, do not want to be governed. This kind of war is by nature just (dikaion). ${ }^{37}$

Here, Aristotle assumes that humans ought to make use of the other animals. In order to make use of wild animals, humans can employ a kind of war against them: they can hunt them. Hunting is the same kind of war that can be directed against people who are by nature meant to be subdued. On the basis of these criteria, Aristotle distinguishes between just wars and unjust wars. Just wars can be directed against two kinds of humans and non-human animals: wild beasts and recalcitrant people who are meant by nature to be governed. ${ }^{38}$ Conversely, war and hunting may be unjust if directed against the wrong kind of humans and non-human animals, including perhaps Athenians and tame animals. If both just and unjust wars against non-human animals are possible, there is a form of justice between human and non-human animals. ${ }^{39}$ On this point, the Eudemian Ethics, the History of Animals and the Politics are in tension with the views on inter-species justice in the Nicomachean Ethics.

Another case in which Aristotle's ethics seems in tension with his biology and anthropology is the exhortation to engage in a contemplative life. As we have seen in the function argument and in the account of natural sociability, Aristotle's views on human nature inform his views of the human good. Sometimes, he even uses biological assumptions to test his ethical views, for example he invokes human political nature to explain why the human happy life cannot be solitary (EN 1.7, 1097b6-16). A similar approach seems suitable for his account of the limits of self-improvement:

Each person wishes for goods for himself. And no one chooses to become another person even if that other will have every good when he has come into being; for, as it is, the god has the good [but no one chooses to be replaced by a god]. Rather [each of us chooses goods] on condition that he remains whatever he is. ${ }^{40}$

We can wish for self-improvement and wish to acquire good things, but this wish is limited by our nature and our identity. We cannot wish to improve our condition by becoming a different kind of being or by becoming another person. A wish of this sort is problematic because it purports to be for self-improvement, while in fact it promotes self-annihilation. While Aristotle here argues that we cannot wish to improve ourselves by transcending our human nature, elsewhere in the corpus he seems to contradict this view:

\footnotetext{
${ }^{37}$ Pol. 1256b23-26

${ }^{38}$ Presumably, in Aristotle's view, the appropriate rulers are Athenian men of high birth.This is a curious view, of course, because Aristotle himself was not an Athenian.

${ }^{39}$ See also Pol. 7.2, 1324b40-41, where Aristotle argues that one should only hunt edible animals. Contra (Sorabji 1993, 118). Sorabji also argues that animals are subject to justice, for Aristotle, because they act voluntarily and are therefore appropriately blamed or praised. This view relies, however, on a controversial account of non-human animal voluntariness, responsibility, praise and blame.

${ }^{40}$ EN 9.4, 1166a20-25. See also EN 8.7, 1159a5-11.
} 
Hence if understanding (nous) is something divine (theion) in comparison with a human being, so also will the life in accord with understanding be divine in comparison with human life. We ought not to follow the makers of proverbs and 'Think human, since you are human', or 'Think mortal, since you are mortal'. Rather, as far as we can, we ought to immortalize (athanatizein), and go to all lengths (panta poiein) to live a life in accord with our supreme element; for however much this element may lack in bulk, by much more it surpasses everything in power and value. Moreover, each person seems to be his understanding (nous), if he is his controlling and better element. It would be absurd, then, if he were to choose not his own life, but something else's. ${ }^{41}$

Here, Aristotle exhorts us toward intellectual contemplation as the best and most divine life. Our understanding is called "divine" and so is the life of understanding as compared to a human life. One should not "think human", but "immortalize" and live the most divine life. The passage concludes with the remark that we are in fact our own divine part, i.e. our understanding, and so a life in accordance with this divine part does not transcend human nature.

Especially if read alongside the passages in which self-improvement must be within the limits of human (not divine) nature, it is difficult to accept that the we should immortalize and that immortalizing does not transcend human nature. In addition, we might think that Aristotle in this context has failed to square his ethico-political views with his account of human nature in the biological works. There, as we have seen, humans appear to have much in common with non-human animals. Even if human understanding is in some sense divine, transcending their animal nature is a way for humans to become other than they are.

Since the role of the theoretical life is among the most intricate and debated topics in the Nicomachean Ethics, it is impossible to assess these tensions within the scope of a short chapter. ${ }^{42}$ Perhaps, these remarks signal that Aristotle's conception of the best human life goes beyond his biological account of humanity. Nonetheless, the tension may be reconcilable if it were possible for human understanding to be both human and divine ${ }^{43}$ and for the exhortation to immortalize to be different from the wish to become a divinity.

\section{Conclusion}

I have suggested that there are significant overlaps between Aristotle's biology and his political science. Sometimes he presupposes some knowledge of biological teleology in the exposition of his views about the human good. In other contexts, by knowing his biology we can reach a better understanding of his ethical and political presuppositions. In other cases still, it is hard to tell whether his political science and his biology actually support each other or they are merely broadly compatible. Furthermore, biological assumptions within Aristotle's own work can be the source of a critique of his political science. This body of evidence shows that studying Aristotle's political science alongside his biological works is a fruitful interpretive exercise.

\footnotetext{
${ }^{41}$ EN 10.6, 1177b30-1178a8.

${ }^{42}$ See (Irwin 2012) for an introduction, see further (Whiting 1986; Charles 1999; Scott 1999;

Lear 2005).

${ }^{43}$ See (Whiting 1986).
} 
The links between Aristotle's ethico-political views and his biology, especially when they are explicitly drawn, also raise the question whether his views on the human good are just as obsolete as his views on the constitution of the blood. Given the plethora of ethical (and biological) questions that Aristotle deals with, the answer to this question is bound to be long and complex. Aristotle's views on justice toward women, slaves and non-human animals are not only obsolete, but also repugnant. However, the view that there are interesting links between biology and political science is on its own worthy of further exploration. In addition, some aspects of Aristotle's investigation on human nature may still be fruitful for a study of the human good, even if the thesis that humans have a function may no longer be plausible. Similarly, a study of the biological preconditions of the virtues, once freed of biased sexist and racist presuppositions, is a useful tool to assess the plausibility of virtue ethics. ${ }^{44}$

\section{Bibliography}

R. Barney (2008) ‘Aristotle's Argument for a Human Function' Oxford Studies in Ancient Philosophy 34: 293-322.

E. Cagnoli Fiecconi (2018) ‘Enmattered Virtues’ Metaphysics 1: 2018.

D. Charles (1999) 'Aristotle on Well-Being and Intellectual Contemplation: David Charles'. Aristotelian Society Supplementary Volume 73 (1): 205-223.

S. M. Connell (2016) Aristotle on Female Animals: A Study of the Generation of Animals (Cambridge: Cambridge University Press).

S. M. Connell (2018) 'From Natural Character to Moral Virtue in Aristotle, by Mariska Leunissen'. Mind 127 (507): 938-46.

J. M. Cooper (1988) 'Political Animals and Civic Friendship' in Reason and Emotion: Essays on Ancient Moral Psychology and Ethical Theory (Princeton: Princeton University Press), pp. 356-78.

D. J. Depew (1995) 'Humans and Other Political Animals in Aristotle's “History of Animals"'. Phronesis 40 (2): 156-181.

M. Deslauriers (2009) ‘Sexual Difference in Aristotle’s Politics and His Biology’ Classical World: A Quarterly Journal on Antiquity 102 (3): 215-31.

J. Gelber (2015a) 'Aristotle on Essence and Habitat' Oxford Studies in Ancient Philosophy 47: 267-293.

J. Gelber (2015b) 'Are Facts about Matter Primitive?' in D. Ebrey (2015) Theory and Practice in Aristotle's Natural Philosophy (Cambridge: Cambridge University Press), pp.4660.

\footnotetext{
${ }^{44}$ This paper has benefitted greatly from Sophia Connell's insightful and helpful comments. Thanks also to Claire Benn, Sharon Berry, Leora Dahan Katz, Elvira Di Bona, Guy Paltieli, Olla Solomyak, Georgie Statham, Casper Storm Hansen, Assaf Tamari and the other participants to the Polonsky seminar for their suggestions and help.
} 
M. L. Gill (1997) 'Material Necessity in Meteorology IV.12' in W. Kullman and S. Föllinger (1997) Aristotelische Biologie, Intentionen, Methode, Ergebnisse (Stuttgart: Franz Steiner Verlag), pp. 145-61.

M. Heath (2008) 'Aristotle on Natural Slavery'. Phronesis 53 (3): 243-70.

D. Henry (2007) 'How Sexist Is Aristotle's Developmental Biology?' Phronesis 52 (3): 251-69.

D. Henry (2018) 'Aristotle on Animals'. In P. Adamson and F. Edwards Animals. A History (Oxford: Oxford University Press), 9-25.

D. Henry and K. M. Nielsen (2015) Bridging the Gap Between Aristotle's Science and Ethics (Cambridge: Cambridge University Press).

T. Irwin (1980) 'The Metaphysical and Psychological Basis of Aristotle's Ethics' in A. Oksenberg Rorty Essays on Aristotle's Ethics (Berkeley: University of California Press), pp. 35-53.

T. Irwin (1999) Aristotle's Nicomachean Ethics (Cambridge: Hackett).

T. Irwin (2012) 'Conceptions of Happiness in the Nicomachean Ethics' in C. Shields The Oxford Handbook of Aristotle (Oxford: Oxford University Press), pp. 495-523.

T. K. Johansen (2012) The Powers of Aristotle's Soul (Oxford: Oxford University Press)

J. Karbowski (forthcoming 2019) 'Political Animals and Human Nature in Aristotle's

Politics' in G. Keil and N. Kreft, Aristotle's Anthropology (Cambridge University Press).

R. Kraut (2018) 'Aristotle's Ethics' in E. N. Zalta (Summer 2018) The Stanford Encyclopedia of Philosophy

https://plato.stanford.edu/archives/sum2018/entries/aristotle-ethics/.

J. Lennox (1997) 'Material and Formal Natures in Aristotle's De Partibus Animalium'. in W. Kullman and S. Föllinger (1997) Aristotelische Biologie, Intentionen, Methode, Ergebnisse (Stuttgart: Franz Steiner Verlag), pp. 161-181.

J. Lennox (1999) 'Aristotle on the Biological Roots of Virtue: The Natural History of Natural Virtue' in J. Maienschein and M. Ruse (1999) Biology and the Foundation of Ethics, (Cambridge: Cambridge University Press), pp. 10-31. Reprinted in D. Henry and K. M. Nielsen (2015) Bridging the Gap Between Aristotle's Science and Ethics (Cambridge: Cambridge University Press), pp.193-213. 
M. Leunissen (2010) Explanation and Teleology in Aristotle's Science of Nature. (Cambridge: Cambridge University Press).

M. Leunissen (2012) 'Aristotle on Natural Character and Its Implications for Moral Development'. Journal of the History of Philosophy 50 (4): 507-30.

M. Leunissen (2015a) 'Aristotle on Knowing Natural Science for the Sake of Living Well' in D. Henry and K. M. Nielsen (2015) Bridging the Gap Between Aristotle's Science and Ethics (Cambridge: Cambridge University Press), 214-31.

M. Leunissen (2015b) 'Perfection and the Physiology of Habituation According to Physics Vii.3’ in M. Leunissen (2015) Aristotle's Physics: A Critical Guide. Cambridge (Cambridge: Cambridge University Press), pp. 225-45.

M. Leunissen (2017) From Natural Character to Moral Virtue in Aristotle (Oxford: Oxford University Press).

C. T. Merleau (2003) 'Bodies, Genders and Causation in Aristotle’s Biological and Political Theory’ Ancient Philosophy 23 (1): 135-51.

K. M. Nielsen (2015) 'The Constitution of the Soul: Aristotle on Lack of Deliberative Authority' Classical Quarterly 65 (2): 572-86.

H. Rackham (1932) Aristotle's Politics. (Cambridge, Mass: Loeb. Harvard University Press).

G. Richardson Lear (2005) Happy Lives and the Highest Good: An Essay on Aristotle's 'Nicomachean Ethics' (Princeton: Princeton University Press).

M. Schofield (2006) 'Aristotle's Political Ethics' in R. Kraut The Blackwell Guide to Aristotle's Nicomachean Ethics (Oxford: Blackwell), pp. 305-22.

D. Scott (1999) 'Aristotle on Well-Being and Intellectual Contemplation: Dominic Scott'. Aristotelian Society Supplementary Volume 73 (1): 225-242.

C. Shields (2015) 'The Science of Soul in Aristotle's Ethics' in D. Henry and K. M. Nielsen (2015) Bridging the Gap Between Aristotle's Science and Ethics (Cambridge: Cambridge University Press), pp. 232-53.

R. Sorabji (1993) Animal Minds and Human Morals: The Origins of the Western Debate (Ithaca: Cornell University Press).

E. Spelman (2003) 'Aristotle and the Politicization of the Soul' in S. Harding and M. B. Hintikka Discovering Reality: Feminist Perspectives on Epistemology, Metaphysics, Methodology, and Philosophy of Science (Dordrecht: Springer Netherlands), pp. 17-30.

T. Tuozzo (1996) 'The Function of Human Beings and the Rationality of the Universe: Aristotle and Zeno on Parts and Wholes'. Phoenix 50 (2): 146-61.

J. Whiting (1986) 'Human Nature and Intellectualism in Aristotle'. Archiv Für Geschichte 
Der Philosophie 68 (1): 70-95.

J. Whiting (1988) 'Aristotle's Function Argument: A Defense'. Ancient Philosophy 8 (1): 33-48. 